\title{
Steam as a Preplant Soil Disinfestant Tool in California Cut-flower Production
}

\author{
Christine M. Rainbolt ${ }^{1}$, Jayesh B. Samtani ${ }^{2}$, Steven A. Fennimore ${ }^{3}$, \\ Celeste A. Gilbert ${ }^{3}$, Krishna V. Subbarao ${ }^{4}$, James S. Gerik ${ }^{5}$, \\ Anil Shrestha ${ }^{1}$, and Bradley D. Hanson ${ }^{6,7}$
}

ADDITIONAL INDEX wORDs. methyl bromide alternatives, weed control, pathogen, lily, sunflower

\begin{abstract}
Summary. Methyl bromide (MB) has been widely used in California cut-flower production for effective control of a broad range of soil pests, including plant pathogens and weeds. However, MB is an ozone-depleting substance, and its availability to growers is limited according to the Montreal Protocol guidelines. Steam has been suggested as a nonchemical option for preplant soil disinfestation. Five trials were conducted in protected greenhouse structure or open-field cutflower nurseries in Monterey, San Luis Obispo, and Ventura counties to evaluate the effect of steam application, alone or in combination with solarization, on soilborne plant pathogen populations, weed densities, and crop growth. Several steam application methods were used including steam blanket, spike-hose, buried drip irrigation lines, or drain tile, and these varied among trials. Calla lily (Zantedeschia aetbiopica) nursery trials initiated in 2007 and 2008 showed that steam alone or with solarization was similar to or more effective than MB:chloropicrin (MBPic), applied via drip lines, in controlling weeds and Verticillium dabliae at 6-inch depth. Trials conducted in Spring and Fall 2009 in an oriental hybrid lily (Lilium sp.) nursery showed that, 112 days after steam treatment (DAT) in the spring, the steam (spike-hose) treatment had fewer Fusarium oxysporum propagules than the MB treatment. Lily plant growth in the steam-treated plots was similar to MB-treated plots and taller than in control plots. In the fall trial, fewer lily plants emerged by 44 DAT in the untreated control than in steam- and MB-treated plots and steam was not as effective as MB in reducing Pythium populations. In the 2010 sunflower (Helianthus annuus) and bupleurum (Bupleurum griffithii) trial, all steam treatments reduced Pythium and Phytophthora cactorum survival compared with the untreated control plots, whereas weed densities were reduced only in the spike-hose steam-treated plots. These trial studies showed that steam appeared as effective as MB in suppressing pathogens and weeds and improving crop growth in cut-flower nurseries. However, additional information on fuel consumption, treatment time efficiency, and long-term effects of steam treatment on soil health are needed before steam can be recommended as a viable alternative to MB in California cut-flower nurseries.
\end{abstract}

$\mathrm{C}$ ut-flower production systems are often complex, with growers continually planting small areas with a range of species and cultivars to ensure year-round availability of the highly perishable crop while also targeting key market windows. The intensity, diversity, and high capital costs inherent in this cropping system have led to a reliance on MB fumigation for preplant control of a broad range of soilborne pathogens, weeds, and nematodes. MB was classified as a Class I stratospheric ozone-depleting substance and became subject to the provisions of the Montreal Protocol in 1993. This international treaty called for elimination of $\mathrm{MB}$ use in developed countries by 2005 and in developing counties by 2015 (Ristaino and Thomas, 1997); however, critical use exemptions for $\mathrm{MB}$ are considered when alternatives are ineffective or not economically feasible (Duniway, 2002; Martin, 2003). In California cut flowers, currently registered chemical alternatives to $\mathrm{MB}$ include 1,3-dichloropropene, chloropicrin (Pic), dazomet, metam potassium, and metam sodium. Because of various efficacy and regulatory concerns, it is unlikely that any of these products alone can replace all MB uses (Gerik and Hanson, 2011). Importantly, few of the currently registered $\mathrm{MB}$ alternatives are labeled in California for use in protected greenhouse structures, a production system that accounts for $\approx 11 \%$ of the cut-flower acreage in the state [U.S. Department of Agriculture (USDA), 2009].

Soil solarization was proven to effectively control plant pathogens and weeds in vegetable and cut-flower production in Turkey and Portugal during the hot summer months when greenhouses were not in production (Ozturk et al., 2002; Reis, 2002). However, fog and cooler soil temperatures make solarization a less optimal tool for pest control in coastal California, where most cut flowers are produced (Elmore et al., 2007). In addition, Stapleton and DeVay (1986) suggest that even under favorable conditions, 4 to 8 weeks is ideal for effective solarization treatment, a substantial reduction in production time in a highvalue crop such as cut flowers.

Steam has been used as a soil and substrate disinfestant since the late 1800s and has been suggested as an effective MB alternative (Newhall, 1955; Pizano, 2006). In the Netherlands, $\approx 50 \%$ of the cut-flower acreage is steam treated for soil disinfestation, and it is also used in Australia, Colombia, Brazil, and Italy (Pizano, 2006). High temperatures can control a wide range of pests, although selectivity and efficacy depend on the temperature and exposure duration (Bollen, 1969; Pullman et al., 1981; van Loenen et al., 2003).

\begin{tabular}{llll}
\hline $\begin{array}{l}\text { Units } \\
\begin{array}{l}\text { To convert U.S. to SI, } \\
\text { multiply by }\end{array}\end{array}$ & U.S. unit & SI unit & $\begin{array}{l}\text { To convert SI to U.S., } \\
\text { multiply by }\end{array}$ \\
\hline 0.4047 & acre(s) & $\mathrm{ha}$ & 2.4711 \\
102.7902 & acre-inch(es) & $\mathrm{m}^{3}$ & 0.0097 \\
29,574 & $\mathrm{fl} \mathrm{oz}$ & $\mu \mathrm{L}$ & $3.3814 \times 10^{-5}$ \\
29.5735 & $\mathrm{fl} \mathrm{oz}$ & $\mathrm{mL}$ & 0.0338 \\
0.3048 & $\mathrm{ft}$ & $\mathrm{m}$ & 3.2808 \\
0.0929 & $\mathrm{ft}^{2}$ & $\mathrm{~m}^{2}$ & 10.7639 \\
2.54 & $\mathrm{inch}(\mathrm{es})$ & $\mathrm{cm}$ & 0.3937 \\
0.4536 & $\mathrm{lb}$ & $\mathrm{kg}$ & 2.2046 \\
1.1209 & $\mathrm{lb} / \mathrm{acre}$ & $\mathrm{kg} \cdot \mathrm{ha}^{-1}$ & 0.8922 \\
1 & $\mathrm{micron}$ & $\mu \mathrm{m}$ & 1 \\
0.0254 & $\mathrm{mil}$ & $\mathrm{mm}$ & 39.3701 \\
28.3495 & $\mathrm{oz}$ & $\mathrm{g}$ & 0.0353 \\
$\left({ }^{\circ} \mathrm{F}-32\right) \div 1.8$ & ${ }^{\circ} \mathrm{F}$ & ${ }^{\circ} \mathrm{C}$ & $\left({ }^{\circ} \mathrm{C} \times 1.8\right)+32$ \\
& & & \\
\end{tabular}


When steam is used in California cut-flower production, typically it is applied with the sheet steaming technique described by Runia (1984) where steam is forced under a heatresistant film and provides pest control as the heat moves down through the soil. This has limited the use of steam disinfestation in open fields because of high energy and labor costs (Fennimore et al., 2008). Efficiency can be improved by applying steam below the soil surface such as through a permanent drain-tile system or by actively pulling steam through the soil (Lu et al., 2010; Newhall, 1955; Runia, 2000); however, these techniques have not been evaluated in coastal California.

The combined effects of solarization and, more efficient, subsurface steam application may increase the viability of steam as a nonfumigant $\mathrm{MB}$ alternative for preplant soil disinfestation. The objective of this research was to evaluate the efficacy of steam treatments for the control of weeds and soil borne plant pathogens using several steam delivery methods and solarization treatments as $\mathrm{MB}$ alternatives in California cut-flower production.

\section{Materials and methods}

DESCRIPTION PERTINENT TO ALL TRIALS. Five single growing season field trials were conducted between 2007 and 2010 in commercial flower

This research was supported by a grant from the USDA-CSREES Methyl Bromide Transitions Program (2007-02951 \& 2008-02972) and funding from the Propane Education and Research Council.

We thank Holland America Flowers, Pyramid Flowers, and Golden State Bulb Growers for generously providing grower space and equipment for the trials and acknowledge the technical support of Matt Gonzalez, Curtis Koga, Patty Mungur, Mary Terrazas, J. Ben Weber, and Stella Zambrzuski.

${ }^{1}$ Plant Science Department, California State University-Fresno, 2415 E. San Ramon Avenue, Fresno, CA 93740

${ }^{2}$ Department of Horticulture, Hampton Roads AREC, Virginia Polytechnic Institute and State University, 1444 Diamond Springs Road, Virginia Beach, VA 23455

${ }^{3}$ Department of Plant Sciences, University of CaliforniaDavis, 1636 East Alisal Street, Salinas, CA 93905

${ }^{4}$ Department of Plant Pathology, University of California-Davis, 1636 East Alisal Street, Salinas, CA 93905

${ }^{5}$ Water Management Research Unit, USDA-ARS San Joaquin Valley Agricultural Sciences Center, 9611 South Riverbend Avenue, Parlier, CA 93648

${ }^{6}$ Department of Plant Sciences, University of CaliforniaDavis, One Shields Avenue, Davis, CA 95616

${ }^{7}$ Corresponding author. E-mail: bhanson@ucdavis. edu. nurseries to evaluate steam soil disinfestation using two experimental protocols. Two open-field calla lily trials were conducted to evaluate treatment combinations of solarization and steam disinfestion. A second experimental protocol was developed based on results in the calla lily trials and was used in subsequent greenhouse oriental hybrid lily trials, one initiated in the spring and one in the fall, and an open-field sunflower/bupleurum trial. In all trials, steam was generated using a diesel- or propane-fired, trailer-mounted boiler (SF-20 or SF-25; Sioux Corp., Beresford, SD) and delivered to the plots through a 3-inch-diameter hose. Steam distribution systems varied slightly among trials (detailed below); however, in each case, steam was applied until the soil temperature exceeded $158^{\circ} \mathrm{F}$ at 10 inch depth. Soil temperature was monitored during steam applications using bimetal thermometers (Reotemp Instrument Corp., San Diego, CA). After $20 \mathrm{~min}$ (calla lily trials) or $30 \mathrm{~min}$ (oriental lily and sunflower/bupleurum trials) above the threshold temperature, the steam application was discontinued and the soil was allowed to cool naturally.

The experimental designs for these trials were randomized complete blocks or completely randomized designs with four to six replicates (Table 1). Data for each of the five trials were separately subjected to analysis of variance (ANOVA) (PROC GLM, SAS version 9.1; SAS Institute, Cary, NC) and means were separated using Fisher's protected least significant difference test with alpha $=0.05$. Before running the ANOVA, data were tested for normality, and log-transformed if necessary. Where transformed data were analyzed, means were backtransformed for presentation.

Trials ON STEAM PLUS SOlARIZATION. Calla lily trials were initiated near Prunedale, CA, in 2007 and 2008 to evaluate the effects of steam, solarization, and solarization + steam disinfestation. Soil at the site was a Santa Ynez fine sandy loam soil, smectitic, thermic Ultic Palexeroll. Treatments in the 2007 trial included an untreated control, MBPic, solarization alone, steam alone, and steam + solarization with steam applied using a steam blanket. In the 2008 trial, treatments included an untreated control, MBPic, solarization alone, steam alone (applied using a spike-hose system), and steam + solarization with steam applied using either a spike-hose or buried pipe. Untreated control plots were not subject to solarization, steaming, or fumigation. Preplant MBPic [67\%/33\% (v/v)] was applied at a commercial standard of $350 \mathrm{lb} /$ acre through the drip irrigation system in 1.6 acre-inches of water. Solarization treatments were imposed by covering the beds with 1.2-mil clear standard polyethylene film (Guardian AgroPlastics, Tampa, FL) and irrigating to raise soil moisture to aid in conduction of heat absorbed from solar irradiance. Soil moisture was considered sufficient if the soil crumbled easily when hand squeezed (Baker, 1957). Solarization occurred from 28 Aug. to 27 Sept. 2007 and 28 Aug. to 21 Sept. 2008 in the two trials.

Steam treatments were applied on 12 or 13 Sept. 2007 and 18, 19, 22 , or 23 Sept. 2008. In case of steam + solarization treated beds, the solarization film was removed during steam application period and replaced after steam treatment. In the 2007 trial, steam was applied to the soil surface through $20-\mathrm{ft} \times 55$-inch steam blankets (Syn-Tex, Winnipeg, $\mathrm{MB}$, Canada). In the 2008 trial, the steam blanket approach was replaced with two subsurface steam delivery systems using buried pipe or spikehose to improve efficiency. In the buried pipe method, steam was applied through 2 -inch-diameter plastic tubing with $1 / 8$-inch-diameter holes spaced every 8 inches serving as outlets for steam into the beds. Two pipes spaced 12 inches apart were installed 8 to 10 inches below the surface in each bed (steam emitted on about an $8 \times 12$-inch grid). In the spike-hose method, steam was delivered through 5-inch-diameter flexible mesh hoses with 8-inch hollow steel spikes spaced 10 inches apart (SynTex). Four rows of spike-hoses were inserted through the polyethylene film into the soil in each plot so that spikes formed $\approx 10 \times 10$-inch grid. For the steam alone treatment, beds were covered with 1.2-mil white polyethylene film (Guardian AgroPlastics) to minimize solarization effects, and steam was delivered to the beds using the spike-hose method.

$V$. dabliae control was assessed in the 2008 trial using previously described techniques (Samtani et al., 
Table 1. Location and experimental details of steam disinfestation trials in California cut-flower nurseries during $2007-10$.

\begin{tabular}{|c|c|c|c|c|c|}
\hline Location & Crop & Production system & Date initiated & Experimental design ${ }^{z}$ & Plot size ${ }^{y}$ \\
\hline Prunedale, CA & Calla lily & Open field & 28 Aug. 2007 & RCBD, 6 replications & $25 \mathrm{ft} \times 55$ inches \\
\hline \multicolumn{6}{|c|}{ Trials on steam application techniques } \\
\hline Nipomo, CA & Oriental hybrid lily & Greenhouse & 23 Feb. 2009 & CRD, 4 replications & $100 \mathrm{ft} \times 42$ inches \\
\hline Nipomo, CA & Oriental hybrid lily & Greenhouse & 28 Sept. 2009 & RCBD , 4 replications & $100 \mathrm{ft} \times 42$ inches \\
\hline
\end{tabular}

${ }^{2} \mathrm{RCBD}=$ randomized complete block design, $\mathrm{CRD}=$ completely randomized design.

${ }^{y} \mathrm{l}$ inch $=2.54 \mathrm{~cm}, \mathrm{l} \mathrm{ft}=0.3048 \mathrm{~m}$.

2012). Briefly, soil infested with $V$. dabliae was collected from a strawberry (Fragaria $\times$ ananassa) field in Watsonville, CA, and 100-g subsamples were placed into $7.5 \times 15-\mathrm{cm}$ mesh bags with $10-\mu \mathrm{m}$ micropores (Delstar Technologies, Middletown, DE) that were heat-sealed. Bags were buried at 6-, 12-, and 18-inch soil depths in the center of the bed before fumigation or steam application. After the final steam treatment, sample bags were recovered and soil was airdried for $28 \mathrm{~d}$. Air-dried soil was passed through a $425-\mu \mathrm{m}$ (40-mesh) sieve, a 10 -g subsample was placed in a screw-capped plastic vial, $2.5 \mathrm{~mL}$ methionine (M-9500; Sigma-Aldrich, St. Louis, MO) $\left(0.0075 \mathrm{~g} \cdot \mathrm{mL}^{-1}\right.$ distilled water) was added, and samples were incubated at $30^{\circ} \mathrm{C}$ for $7 \mathrm{~d}$. After incubation, soil was air-dried at room temperature $\left(23 \pm 1^{\circ} \mathrm{C}\right)$ for $7 \mathrm{~d}$ before soil was gently pulverized and plated onto six plates containing modified NP-10 medium (Kabir et al., 2004) using the Anderson sampler technique (Butterfield and DeVay, 1977). The plates were incubated for $21 \mathrm{~d}$ in the dark at room temperature. Following incubation, the soil was gently washed from the surface of each plate, and microsclerotial colonies of $V$. dabliae on each plate were counted (Kabir et al., 2004). Since 0.5 -g soil is distributed on six NP-10 plates, the $\mathrm{cu}^{-}$ mulative microsclerotial counts from the six plates were doubled to obtain the number of microsclerotia per gram of soil. In addition to the experimental control, an internal control soil with known number of microsclerotia was also included to ensure that the technique provided consistent results.

Treatment effect on weed seed viability was evaluated in both calla lily trials. Twenty-five seeds of common chickweed (Stellaria media), common knotweed (Polygonum arenastrum)
(2008 trial only), common purslane (Portulaca oleracea), and little mallow (Malva parviflora) were placed in $8 \times$ $12-\mathrm{cm}$ heat-sealed nylon mesh bags. Common knotweed and common chickweed seeds were purchased (Herbiseed, UK) while little mallow and common purslane seed were collected from agricultural fields near Salinas, CA. Seed bags were buried at two locations (bed center and edge) and at two depths (2 and 6 inches) in each plot. Following treatment, bags were removed and seed viability was assessed using the tetrazolium assay described by Baalbaki et al. (2009).

Calla lily was seeded on 19 Oct. 2007 and on 18 Oct. 2008 in the first and second trial, respectively. The calla lily crop was managed by the cooperating grower using standard production practices. During the growing season, crop emergence and growth parameters were evaluated by research personnel. Weed control was assessed by measuring total fresh shoot and root weed biomass, total weed density counts, and hand-weeding time for each plot.

Trials on STEAM application TECHNIQUES. Based on the results of the 2007 and 2008 trials, three additional trials were conducted in 2009 and 2010 to compare efficacy of two steam application techniques. In these trials, performance of the spike-hose steam application technique was compared with steam injected through subsurface plastic drain tile. Two oriental hybrid lily trials were conducted in protected greenhouse structure in Spring and Fall 2009 near Nipomo, CA. The soil at this site was Oceano sand, a mixed, thermic Lamellic Xeropsamment, and treatments included an untreated control and two steam treatments. For comparison purposes, a hot gas MB treatment was applied to plots adjacent to the experiment; however, this replicated treatment could not be randomized among the steam treatments because of logistical limitations and safety concerns. The spike-hose steam treatment was similar to the method used in the 2008 calla lily trial. Beds were covered with clear, l-mil polyethylene film (Pliant Corp., Washington, GA), and steam was injected through four rows of spikehoses. In the drain-tile steam treatment, four rows of 3 -inch perforated polyethylene drain tile (Hancor, Findlay, $\mathrm{OH}$ ) were buried 12 inches deep in the bed and connected to a manifold for subsurface steam application. In the fall trial, insulating pads were installed on the bed surface during steam application in an effort to increase fuel efficiency of the disinfestation treatments.

$\mathrm{MB}$ was applied in the spring oriental hybrid lily trial on 12 Feb. 2009 , and steam was applied on 23 and $24 \mathrm{Feb}$. The grower planted several lily cultivars during the week following steam treatment. In the first $15 \mathrm{~m}$ of the bed, all plots included the cultivars Mother's Choice, Mero Star, Starfighter, and Rialto. In the second lily trial, steam was applied on 28 and 29 Sept. 2009 and MB was applied on 1 Oct. Two replicates of the steam and untreated plots were planted 9 DAT and the remaining two replicates and the MB-treated plots were planted 23 DAT. The oriental hybrid lily cultivar, Sorbonne, was planted in the steam- and untreated plots with the exception of one untreated plot, which was planted with the cultivar Nymph. The cultivar Dynamite was planted in the MB-treated plots.

A final cut-flower nursery trial was conducted in Summer 2010 in an open-field production area near Oxnard, CA, with a Metz loamy sand, a mixed, thermic Typic Xerofluvent. In this trial, steam was applied on 8 
and 9 June 2010 using the previously described spike-hose and drain-tile systems. No MB treatment was included in this trial because of grower constraints. Beds in each plot were covered with 1 -mil polyethylene film, and insulating pads were used during steam application to increase treatment efficiency. The grower seeded half of the trial with bupleurum and half with sunflower $\approx 30$ DAT.

Naturally occurring populations of Fusarium oxysporum and Pythium were quantified from soil samples collected following treatments in the 2009 and 2010 trials. Soil samples were collected 1 DAT for all plots in the spring oriental hybrid lily trial, 1 DAT for steam- and untreated control plots and 44 DAT for MB plots in the fall oriental hybrid lily trial, and 9 DAT for all plots in the sunflower/ bupleurum trial. In addition, the oriental hybrid lily trials were resampled at the conclusion of the trials (112 and 142 DAT). Soil samples were composites of five to six cores taken from the top 6 inches of soil in each plot. Soil was allowed to air dry for at least two weeks in the laboratory, and populations of both pathogens were determined by dilution plating using a sample solution in which $1 \mathrm{~g}$ soil was added to $10 \mathrm{~mL}$ sterile, deionized water. For F. oxysporum, $300 \mu \mathrm{L}$ sample solution was spread on five petri plates containing Komada's medium (Komada, 1975) and incubated in diffused light at room temperature (21-24 ${ }^{\circ} \mathrm{C}$ ) for 5 to $6 \mathrm{~d}$ before colonies were counted. For Pythium, 500 $\mu \mathrm{L}$ sample solution was spread on five petri plates containing $\mathrm{P}_{5} \mathrm{ARP}$ medium (Jeffers and Martin, 1986). Plates were incubated in the dark at room temperature, and colonies were counted after 24 and $48 \mathrm{~h}$ (Klose et al., 2008). In the sunflower/bupleurum trial, surviving populations of $V$. dabliae and $P$. cactorum were quantified from artificially inoculated soil contained in sample bags. Two $3.5 \times 5$-inch Huboc sand sample bags (Hutchinson Bag Corp., Hutchinson, KS) containing $10 \mathrm{~mL}$ infested soil were buried 6 inches deep in each plot and retrieved 9 DAT; results from each were averaged for mean propagules per gram for each plot. Air-dried soil samples were assayed for $V$. dabliae populations using the Anderson Sampler technique. Populations of $P$. cactorum were determined by dilution plating using a sample solution of $\mathrm{l} g$ air-dried soil mixed in $10 \mathrm{~mL}$ sterile, deionized water. Sample solution $(500 \mu \mathrm{L})$ was pipetted onto five petri plates of semiselective $\mathrm{P}_{10} \mathrm{ARPH}$ medium (Jeffers and Martin, 1986). Petri plates were incubated in the dark at room temperature, and colony counts were made 3 and $5 \mathrm{~d}$ after inoculation.

Weed density was determined in $0.5-\mathrm{m}^{2}$ areas in each plot once or twice during the growing season in the 2009 and 2010 trials. Data were collected 29 and 64 DAT in the spring oriental hybrid lily trial, 44 and 75 DAT in the fall oriental hybrid lily trial, and 48 DAT in the sunflower/bupleurum trial. In the oriental hybrid lily trials, weeds were counted in two to four quadrats in each main plot, and subsample data were averaged, whereas only one quadrat per plot was sampled in the sunflower/bupleurum trial. Weed emergence was recorded separately for each species and data were summed for total weeds per sample. Treatment effects on little mallow, yellow sweetclover (Melilotus officinalis), prickly lettuce (Lactuca serriola), and common groundsel (Senecio vulgaris) were compared as well as effects on total grass weeds, total broadleaf weeds, and total weed populations in the sunflower/ bupleurum trial. However, in the two greenhouse trials, populations of individual species were too low for meaningful comparison and weed count data were summed across all species.

Treatment effects on crop emergence and crop height were assessed in the two oriental hybrid lily trials, and total saleable crop yield was determined in the spring oriental hybrid lily trial only. Lily emergence was evaluated 29 and 64 DAT for the spring oriental hybrid lily trial and 44 and 75 DAT for the fall trial. Emerged crop plants were counted and averaged for four $0.5-\mathrm{m}^{2}$ areas in each plot in the spring oriental hybrid lily trial and in two $0.5-\mathrm{m}^{2}$ areas in the fall oriental hybrid lily trial. Crop height was measured from the soil surface to the base of the leaf axil of the uppermost leaf 85 and 89 DAT in the first and second lily trials, respectively. In the spring oriental hybrid lily trial, height of 20 lily plants in each plot was measured, and in the fall oriental hybrid lily trial, height of 12 lily plants was measured in plots planted with the cultivar Sorbonne. Because of cultivar differences, height data were not collected in the MBtreated plots. Crop yield in the spring oriental hybrid lily trial was collected by the cooperating nursery during a one-month period beginning in early June 2009 (95 DAT). Percent yield was determined for each bed by dividing the number of flowers harvested by the number of bulbs planted. The mixed planting in the sunflower/ bupleurum trial precluded collection of meaningful crop performance data.

\section{Results}

TRIALS ON STEAM PLUS SOLARIZATION. In the 2008 calla lily trial, $V$. dabliae microsclerotia survival in the steam treatments was comparable to MBPic and lower than the untreated control at the 6-inch depth (Table 2); however, solarization alone did not reduce $V$. dabliae survival at 6 inches. At 12 inches, $V$. dabliae survival was lower in the MBPic, steam

Table 2. Soil treatment effects on the survival of Verticillium dabliae microsclerotia placed at 6-, 12-, and 18 -inch $(15.2,30.5$, and $45.7 \mathrm{~cm})$ depths relative to the corresponding internal control in a 2008 calla lily trial near Prunedale, CA.

\begin{tabular}{lccc}
\hline & \multicolumn{3}{c}{ Depth } \\
\cline { 2 - 4 } Treatment & $\mathbf{6}$ inches & 12 inches & $\mathbf{1 8}$ inches \\
\cline { 2 - 4 } & $141.0 \mathrm{a}^{\mathrm{y}}$ & $157.0 \mathrm{a}$ & $149.0 \mathrm{a}$ \\
Untreated $_{\text {Methyl bromide:chloropicrin }}{ }^{\mathrm{x}}$ & $10.0 \mathrm{c}$ & $9.0 \mathrm{c}$ & $16.0 \mathrm{c}$ \\
Solarization & $108.0 \mathrm{ab}$ & $140.0 \mathrm{a}$ & $142.0 \mathrm{a}$ \\
Steam (pipe) + solarization & $12.0 \mathrm{c}$ & $15.0 \mathrm{c}$ & $49.0 \mathrm{bc}$ \\
Steam (spike-hose) + solarization & $24.0 \mathrm{c}$ & $109.0 \mathrm{ab}$ & $138.0 \mathrm{a}$ \\
Steam (spike-hose) & $65.0 \mathrm{bc}$ & $56.0 \mathrm{bc}$ & $107.0 \mathrm{ab}$ \\
$P$ value & $<0.0001$ & $<0.0001$ & 0.0005 \\
\hline
\end{tabular}

${ }^{2}$ Percent survival is relative to the internal control.

${ }^{y}$ Means with the same letter within a column are not significantly different according to Fisher's protected least significant difference test at $P=0.05$.

${ }^{x}$ Methyl bromide:chloropicrin was applied at $350 \mathrm{lb} /$ acre $\left(392.3 \mathrm{~kg} \cdot \mathrm{ha}^{-1}\right)$. 
(pipe) + solarization, and spike-hose treatment than the untreated control, and it was lower in the MBPic and steam (pipe) + solarization treatments than the untreated control at 18 inches.

There was a significant treatment $x$ depth interaction for common chickweed, common purslane, and little mallow viability in the 2007 calla lily trial (Table 3 ) and for common chickweed in 2008 (Table 4). Although MBPic-treated plots usually had the lowest weed seed viability, all treatments with the exception of solarization alone reduced common chickweed and common purslane viability compared with untreated control (Table 3). Common chickweed viability tended to be higher at 6 inches than at 2 inches with the solarization and steam (blanket) treatments in 2007 presumably because of less heat penetration into the bed. For common purslane, the viability trend was similar for steam (blanket) treatments. There were fewer effects of burial depth on annual weed seed viability when the pipe and spikehose steam injection systems were used instead of the steam blanket (Table 4). All treatments in both trials reduced little mallow viability compared with the untreated control with the best control obtained from steam + solarization treatments (Tables 3 and 4 ). In the 2008 trial, common purslane and common knotweed viability in steam + solarization treatments was lowest and comparable to MBPic treatment.

Predominate weeds in the 2007 trial were hairy vetch (Vicia villosa), redstem filaree (Erodium cicutarium), and barley (Hordeum sp.). The untreated

Table 3. Effect of soil treatment and depth on viability of weed seed placed at 2and 6-inch $(5.1$ and $15.2 \mathrm{~cm})$ depths in a 2007 calla lily trial near Prunedale, CA.

\begin{tabular}{|c|c|c|c|c|c|c|}
\hline \multirow[b]{3}{*}{ Treatment } & \multicolumn{2}{|c|}{ STEME $^{\mathrm{z}}$} & \multicolumn{2}{|c|}{ POROL $^{z}$} & \multicolumn{2}{|c|}{ MALPA $^{z}$} \\
\hline & 2 inches & 6 inches & 2 inches & 6 inches & 2 inches & 6 inches \\
\hline & \multicolumn{6}{|c|}{ Viability $(\%)^{y}$} \\
\hline Untreated & $48.7 \mathrm{a}^{\mathrm{x}}$ & $52.0 \mathrm{a}$ & $86.0 \mathrm{a}$ & $79.3 \mathrm{ab}$ & $73.7 \mathrm{a}$ & $66.0 \mathrm{a}$ \\
\hline $\begin{array}{l}\text { Methyl } \\
\text { bromide:chloropicrin }\end{array}$ & $0.0 \mathrm{~cd}$ & $0.0 \mathrm{~cd}$ & 0.3 ef & $0.0 \mathrm{ef}$ & $21.3 \mathrm{~d}$ & $36.7 \mathrm{bc}$ \\
\hline Solarization & $22.1 \mathrm{~b}$ & $47.2 \mathrm{a}$ & $62.7 \mathrm{bc}$ & $55.0 \mathrm{c}$ & $34.0 \mathrm{~cd}$ & $29.7 \mathrm{~cd}$ \\
\hline Steam (blanket) & $0.0 \mathrm{de}$ & $16.3 \mathrm{bc}$ & $0.0 \mathrm{f}$ & $14.7 \mathrm{de}$ & $21.4 \mathrm{~d}$ & $48.7 \mathrm{~b}$ \\
\hline $\begin{array}{l}\text { Steam (blanket) }+ \\
\text { solarization }\end{array}$ & $0.0 \mathrm{c}-\mathrm{e}$ & $15.3 \mathrm{~b}-\mathrm{d}$ & $0.7 \mathrm{ef}$ & $21.7 \mathrm{~d}$ & $1.7 \mathrm{e}$ & $21.3 \mathrm{~d}$ \\
\hline$P$ value & \multicolumn{2}{|c|}{0.0492} & \multicolumn{2}{|c|}{0.0195} & \multicolumn{2}{|c|}{$<0.0001$} \\
\hline
\end{tabular}

${ }^{2} \mathrm{STEME}=$ common chickweed POROL $=$ common purslane, $\mathrm{MALPA}=$ little mallow

ySeed viability is averaged across two locations (bed shoulder or center).

${ }^{x}$ Means with the same letter across depths for each weed species are not significantly different according to Fisher's protected least significant difference test at $P=0.05$.

"Methyl bromide:chloropicrin was applied at $350 \mathrm{lb} / \mathrm{acre}\left(392.3 \mathrm{~kg} \cdot \mathrm{ha}^{-1}\right)$.

Table 4. Effect of soil treatment and depth [ 2 and 6 inches $(5.1$ and $15.2 \mathrm{~cm})$ for common chickweed] and the soil treatment main effect (for other weed species) on weed seed viability in the 2008 calla lily trial near Prunedale, CA.

\section{STEME}

2 inches 6 inches POROL $^{z}$ MALPA $^{z}$ POARI $^{z}$

Treatment

\begin{tabular}{lrrrrr}
\hline Untreated & $63.5 \mathrm{a}^{\mathrm{x}}$ & $68.5 \mathrm{a}$ & $79.8 \mathrm{a}^{\mathrm{x}}$ & $76.5 \mathrm{a}$ & $72.0 \mathrm{a}$ \\
Methyl & $0.0 \mathrm{~d}$ & $0.0 \mathrm{~d}$ & $0.0 \mathrm{c}$ & $34.0 \mathrm{bc}$ & $0.0 \mathrm{~d}$ \\
$\quad$ bromide:chloropicrin & & & & & \\
Solarization & $34.5 \mathrm{~b}$ & $63.0 \mathrm{a}$ & $71.0 \mathrm{a}$ & $47.3 \mathrm{~b}$ & $54.3 \mathrm{~b}$ \\
Steam (pipe) + solarization & $0.0 \mathrm{~d}$ & $0.0 \mathrm{~d}$ & $0.0 \mathrm{c}$ & $1.5 \mathrm{e}$ & $0.0 \mathrm{~d}$ \\
Steam & $4.5 \mathrm{~cd}$ & $9.0 \mathrm{~cd}$ & $11.8 \mathrm{bc}$ & $17.8 \mathrm{~d}$ & $7.5 \mathrm{~d}$ \\
$\quad$ spike-hose) + solarization & & & & & \\
Steam (spike-hose) & $15.0 \mathrm{c}$ & $15.0 \mathrm{c}$ & $22.0 \mathrm{~b}$ & $26.5 \mathrm{~cd}$ & $20.3 \mathrm{c}$ \\
$\begin{array}{l}P \text { value } \\
\text { S }\end{array}$ & 0.0401 & $<0.0001$ & $<0.0001$ & $<0.0001$ \\
\hline
\end{tabular}

${ }^{2}$ STEME $=$ common chickweed, POROL $=$ common purslane, $\mathrm{MALPA}=$ little mallow, POARII $=$ common knotweed

'Seed viability is averaged across two locations (bed shoulder or center) and two depths ( 2 and 6 inches) for POROL, MALPA, and POARII.

${ }^{x}$ Means with the same letter across columns for STEME and within a column for other weed species, are not significantly different according to Fisher's protected least significant difference test at $P=0.05$.

"Methyl bromide:chloropicrin was applied at $350 \mathrm{lb} / \mathrm{acre}\left(392.3 \mathrm{~kg} \cdot \mathrm{ha}^{-1}\right)$. control had the highest weed biomass and weed density, and needed the most time to hand weed (Table 5). Weed biomass was the lowest in the steam treatments while weed density and hand-weeding times were the lowest in steam (blanket), steam (blanket) + solarization, and MBPic treatments. Predominate weeds in the 2008 calla lily trial included California burclover (Medicago polymorpha), hairy vetch, and common groundsel. In 2008 , only steam (pipe) + solarization treatment was more effective than the untreated control in reducing weed density and biomass (data not shown). No differences were observed among treatments for hand-weeding time in 2008.

Trials on steam application TECHNIQUES. At the conclusion of the spring oriental hybrid lily trial (112 DAT), the spike-hose steam treatment had lower $F$. oxysporum populations than the MB treatment and untreated control (Table 6). The drain-tile steam treatment had populations of $F$. oxysporum similar to the spike-hose steam and MB treatments, and a lower population compared with the untreated control. The MB treatment and the untreated control had highest populations. In the fall oriental hybrid lily trial, Pythium population was lowest in the $\mathrm{MB}$ treatment 1 DAT. Steam treatments had populations similar to the untreated control. However, Pythium populations were reduced in the steam treatments compared with the untreated control in the sunflower/bupleurum trial. Similarly, P. cactorum populations were lower in both steam treatments compared with the untreated control.

Weed density 29 DAT in the spring oriental lily trial was lower in all treatments compared with the untreated control but was lowest in the MB-treated plots (Table 7). The draintile steam treatment had results similar to the MB and spike-hose steam treatments. At 64 DAT, steam and MB treatments had similar total weed densities and were lower than the untreated control. There was no treatment effect on weed density in the fall oriental hybrid lily trial.

In the open-field sunflower/ bupleurum trial, little mallow, yellow sweetclover, prickly lettuce, and common groundsel densities accounted for $86 \%$ of the total weeds in all treatments 48 DAT. The spike-hose 
Table 5. Effect of soil treatments on cumulative weed biomass, weed density, and hand-weeding time extrapolated to a per acre basis in a 2007 calla lily trial near Prunedale, CA.

\begin{tabular}{lccc}
\hline Treatment & $\begin{array}{c}\text { Weed biomass } \\
(\mathbf{k g} / \text { acre })^{\mathrm{z}}\end{array}$ & $\begin{array}{c}\text { Weed density } \\
(\mathbf{1 0 0 0 / a c r e})^{\mathrm{z}}\end{array}$ & $\begin{array}{c}\text { Hand-weeding } \\
\text { time }(\mathbf{h} / \text { acre })^{\mathrm{z}}\end{array}$ \\
\hline Untreated $^{\text {Methyl bromide:chloropicrin }}{ }^{\mathrm{x}}$ & $3095.5 \mathrm{a}^{\mathrm{y}}$ & $610.6 \mathrm{a}$ & $285.1 \mathrm{a}$ \\
Solarization & $741.2 \mathrm{~b}$ & $36.8 \mathrm{bc}$ & $70.1 \mathrm{bc}$ \\
Steam (blanket) & $628.9 \mathrm{~b}$ & $52.4 \mathrm{~b}$ & $83.6 \mathrm{~b}$ \\
Steam (blanket) + solarization & $267.1 \mathrm{c}$ & $23.7 \mathrm{c}$ & $55.5 \mathrm{c}$ \\
Pvalue & $517.1 \mathrm{bc}$ & $22.1 \mathrm{c}$ & $49.5 \mathrm{c}$ \\
\hline
\end{tabular}

${ }^{2} 1 \mathrm{~kg} /$ acre $=2.2046 \mathrm{lb} /$ acre $=2.4711 \mathrm{~kg} \cdot \mathrm{ha}^{-1}, \mathrm{l}$ weed $/$ acre $=2.4711$ weeds $/ \mathrm{ha}, \mathrm{l} \mathrm{h} /$ acre $=2.4711 \mathrm{~h} \cdot \mathrm{ha}^{-1}$.

y Means with the same letter within a column are not significantly different according to Fisher's protected least significant difference test at $P=0.05$.

${ }^{x}$ Methyl bromide:chloropicrin was applied at $350 \mathrm{lb} /$ acre $\left(392.3 \mathrm{~kg} \cdot \mathrm{ha}^{-1}\right)$.

steam treatment had lower yellow sweetclover and total weed density compared with the untreated control, and the drain-tile steam treatment had similar densities to both the spikehose treatment and the untreated control.

In the spring oriental hybrid lily trial, crop plants in the drain-tile steam, spike-hose steam, and $\mathrm{MB}$ treatments (39, 38, and 39 inches, respectively) were taller than the untreated control (35 inches); however, no differences were noted in the yield of saleable flowers (data not shown). In the fall oriental hybrid lily trial, no differences in lily height were detected between steam treatments and the untreated control (data not shown). This may be attributed to the differences in growing season as disease pressure is typically greater in warmer periods of the year. Crop emergence 44 DAT was lower in the untreated control (63.6 plants $/ \mathrm{m}^{2}$ ) compared with drain-tile steam, spike-hose steam, and MB treatments $(70.2,71.6$, and 68.8 plants/ $\mathrm{m}^{2}$, respectively).

\section{Discussion}

Although treatment differences were not always detected in the trials, when they occurred, steam treatments generally performed better than the untreated control and were comparable to MB for weed control. Weed control results in the 2007 calla lily trial were consistent with those in strawberry and snapdragon (Antirrbinum sp.) studies where steam provided weed control comparable to or better than MBPic fumigation (Samtani et al., 2011, 2012; Solis and Calderon, 2002). For weed seed viability, where the treatment $\times$ depth interaction was significant, seed viability increased with increasing depth for many treatments. In the 2008 calla lily trial, differences among treatments were small for weed biomass, weed density, and handweeding times, likely due to low weed population at the site. In 2008, inoculated $V$. dabliae microsclerotia control by all steam treatments was comparable to MBPic at 6-inch depth but at 18 -inch depth, only steam (pipe) treatment controlled $V$. dabliae microsclerotia similar to MBPic. In both trials, there was no weed control benefit to combining solarization with steam treatments compared with steam alone, which is consistent with the results of a previous study in strawberry (Samtani et al., 2012).

In the spring oriental hybrid lily trial, weed density was similar in drain-tile steam and MB treatments at $29 \mathrm{DAT}$, but spike-hose steam was no more effective than the untreated control. The opposite was observed in the sunflower/bupleurum trial where total weed density was reduced in the spike-hose steam treatment, but the drain-tile steam treatment was not different from the untreated control. Although the grower was able to plant the crop with the drain tile in place in both oriental hybrid lily trials, the drain tile was removed after steaming but before planting in the sunflower/bupleurum, possibly contaminating the beds with untreated soil. Lack of differences in weed control in the fall planted oriental hybrid lily trial was attributed to extremely variable weed densities among replicates because of staggered planting dates and preplant weed-control practices.

In the sunflower/bupleurum trial, pathogen populations were evaluated before removing the drain tile, and

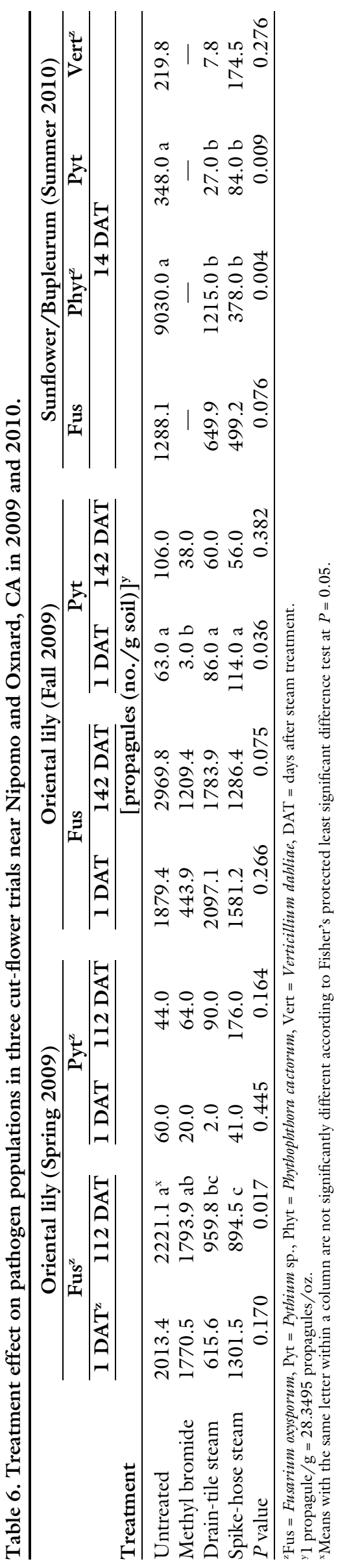

Hortlechnology · April 2013 23(2) 


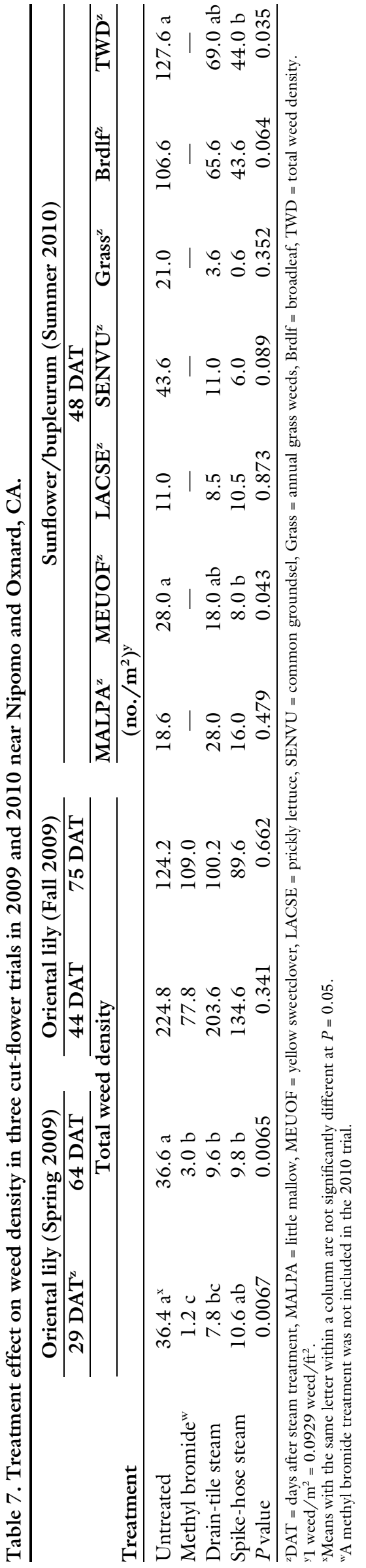

both steam treatments reduced populations of $P$. cactorum and Pythium Similarly, steam applied at $90{ }^{\circ} \mathrm{C}$ for at least $30 \mathrm{~min}$ reduced disease incidence because of Pythium equal to or better than $\mathrm{MB}$ in snapdragon (Solis and Calderon, 2002). Results have been mixed on the effectiveness of steam to control F. oxysporum (O'Neill and Green, 2010; Reuven et al., 2004). In these trials, with the exception of the spring planted oriental hybrid lily trial at 112 DAT, no treatment differences were detected for F. oxysporum. It was expected that at least the $\mathrm{MB}$ treatment would have lower F. oxysporum populations than the untreated control. The lack of differences may be explained by the generally low population numbers and variable nature of pathogen distribution. However, F. oxysporum populations 112 DAT in the steam treatments were lower or similar to $\mathrm{MB}$ suggesting that steam may have been effective in reducing the $F$. oxysporum population over time. Pathogen control results also indicate that steam treatment did not lead to a rapid increase in plant pathogen populations because of a biological vacuum, a concern often expressed when steaming at high temperatures or for long durations. Steam did not inhibit plant growth, and in the spring oriental hybrid lily trial, there was a positive growth response in the steam-treated plots relative to the untreated control. Studies on other horticultural crops have shown preplant steam treatments can have positive effect on crop growth and yields because of the control of soilborne pathogens (Luvisi et al., 2006; Moyls and Hocking, 1994).

These field experiments were conducted on grower farms to evaluate the performance and logistics of thermal soil disinfestation in cut-flower nurseries. Although operational constraints and market needs of the cooperating growers influenced factors such as MB treatment, cultivar selection, and planting date, conducting trials under the rigors and limitations of these specialized systems provides unique insight into the viability of steam as $\mathrm{MB}$ alternative. There were no consistent and clear advantages of using one steam delivery method over other in these studies. Where there were differences among treatments, steam injected below the surface generally performed well and gave pest control equivalent to $\mathrm{MB}$; however, the process was labor and energy intensive. Additional testing of steam soil disinfestation techniques and improvements in time and energy efficiency is needed before steam can be recommended as a viable replacement to MB for California cutflower production.

\section{Literature cited}

Baalbaki, R.Z., S.G. Elias, S. MarcosFilho, and M.B. McDonald. 2009. Seed vigor testing handbook. Contribution \#32. Assn. Official Seed Analysts, Ithaca, NY.

Baker, K.F. 1957. The U.C. System: A general summary, p. 3-27. In: K.F. Baker (ed.). The U.C. system for producing healthy container-grown plants. California Agr. Expt. Sta. Ext. Serv. Manual 23.

Bollen, G.J. 1969. The selective effect of heat treatment on the microflora of a greenhouse soil. Eur. J. Plant Pathol. 75: 157-163.

Butterfield, E.J. and J.E. DeVay. 1977. Reassessment of soil assays for Verticillium dabliae. Phytopathology 67:10731078.

Duniway, J.M. 2002. Status of chemical alternatives to methyl bromide for preplant fumigation of soil. Phytopathology 92:1337-1343

Elmore, C.L., J.D. MacDonald, H. Ferris, A. Chase, H. Ajwa, K. Robb, C. Wilen, I. Zasada, S. Fennimore, and S. Tjosvold. 2007. Soil pests of floriculture crops and potential control with methyl bromide alternatives in California. 28 Feb. 2011. <http://ucanr.org/sites/mb3/Papers/>.

Fennimore, S., A. Spataru, and N. Leslie. 2008. Steam and heat for soil disinfestation. Methyl bromide alternatives outreach. Proc. 2008 Annu. Intl. Res. Conf. Methyl Bromide Alternatives Emissions Reductions. p. 58.

Gerik, J.S. and B.D. Hanson. 2011. Drip application of methyl bromide alternative chemicals for control of soilborne pathogens and weeds. Pest Mgt. Sci. 67:11291133.

Jeffers, S.N. and S.B. Martin. 1986. Comparison of two media selective for Phytophthora and Pythium species. Plant Dis. 70:1038-1043.

Kabir, Z., R.G. Bhat, and K.V. Subbarao. 2004. Comparison of media for recovery of Verticillium dabliae from soil. Plant Dis. 88:49-55.

Klose, S., H.A. Ajwa, G.T. Browne, K.V. Subbarao, F.N. Martin, S.A. Fennimore, 
and B.B. Westerdahl. 2008. Dose response of weed seeds, plant-parasitic nematodes, and pathogens to twelve rates of metam sodium in a California soil. Plant Dis. 92:1537-1546.

Komada, H. 1975. Development of a selective medium for quantitative isolation of Fusarium oxysporum from natural soil. Rev. Plant Protection Res. 8:114-125.

Lu, P., D. Ricauda Aimonino, G. Gilardi, M.L. Gullino, and A. Garibaldi. 2010. Efficacy of different steam distribution systems against five soilborne pathogens under controlled laboratory conditions. Phytoparasitica 38:175-189.

Luvisi, A., A. Materazzi, and E. Triolo. 2006. Steam and exothermic reactions as alternative techniques to control soilborne diseases in basil. Agron. Sustainable Dev. 26:201-207.

Martin, F.N. 2003. Development of alternative strategies for management of soil-borne pathogens currently controlled with methyl bromide. Annu. Rev. Phytopathol. 41:325-350.

Moyls, A.L. and R.P. Hocking. 1994. In situ soil steaming for the control of apple replant disease. Appl. Eng. Agr. 10:59-63.

Newhall, A.G. 1955. Disinfestation of soil by heat, flooding, and fumigation. Bot. Rev. 21:189-250.

O'Neill, T.M. and K.R. Green. 2010. Evaluation of some pre-plant soil treatments and chemical disinfectants for control of fusarium wilt diseases in protected cut flowers. Acta Hort. 883:215-222.
Ozturk, A., S. Yilmaz, M. Keceki, A. Unlu, A. Deviren, A. Ozcelik, S. Cetinkaya, H. Cevri, F. Akkaya, and C. Ozkan. 2002. Alternatives to methyl bromide for tomato and cucumber production in Turkey. Proc. Intl. Conf. Alternatives to Methyl Bromide. p. 209-212.

Pizano, M. (ed.). 2006. Report of the methyl bromide technical options committee. 28 Feb. 2011. <http://ozone.unep. org/teap/Reports/MBTOC/index. shtml>.

Pullman, G.S., J.E. DeVay, and R.H. Garber. 1981. Soil solarization and thermal death: A logarithmic relationship between time and temperature for four soilborne plant pathogens. Phytopathology 71:959-964.

Reis, L. 2002. The use of methyl bromide alternatives in cut-flower production in Portugal. Proc. Intl. Conf. Alternatives Methyl Bromide. p. 243-246.

Reuven, M., Y. Szmulewich, I. Kolesnik, A. Gamliel, V. Zilberg, M. Mor, Y. Cahlon, and Y. Ben-Yephet. 2004. Methyl bromide alternatives for controlling fusarium wilt and root knot nematodes in carnations. Acta Hort. 698:99-104.

Ristaino, J.B. and W. Thomas. 1997. Agriculture, methyl bromide, and the ozone hole: Can we fill the gaps? Plant Dis. 81:964-977.

Runia, W.T. 1984. A recent development in steam sterilization. Acta Hort. 152:195-199.

Runia, W.T. 2000. Steaming methods for soils and substrates. Acta Hort. 532:115124.
Samtani, J.B., H.A. Ajwa, J.B. Weber, G.T. Browne, S. Klose, J. Hunzie, and S.A. Fennimore. 2011. Evaluation of non-fumigant alternatives to methyl bromide for weed control and crop yield in California strawberries (Fragaria ananassa L.). Crop Protection 30:45-51.

Samtani, J.B., C. Gilbert, J.B. Weber, K.V. Subbarao, R.E. Goodhue, and S.A. Fennimore. 2012. Effect of steam and solarization treatments on pest control, strawberry yield, and economic returns relative to methyl bromide fumigation. HortScience 47:64-70.

Solis, L. and L. Calderon. 2002. Alternatives to methyl bromide for cut-flower production in Guatemala. Proc. Intl. Conf. Alternatives Methyl Bromide. p. 253-255.

Stapleton, J.J. and J.E. DeVay. 1986. Soil solarization: A non-chemical approach for management of plant pathogens and pests. Crop Protection 5:190-198.

U.S. Department of Agriculture. 2009. 2007 Census of agriculture-State data. 28 Feb. 2012. <http://www.agcensus. usda.gov/Publications/2007/Full_ Report/index.asp $>$.

van Loenen, M.C.A., Y. Turbett, C.E. Mullins, N.E.H. Feilden, M.J. Wilson, C. Leifert, and W.E. Seel. 2003. Low temperature-short duration steaming of soil kills soil-borne pathogens, nematode pests and weeds. Eur. J. Plant Pathol. 109:993-1002. 